\title{
Pakhtun Women And The Creative Expression: A Means Of Quotidian Agency
}

\author{
Anoosh W. Khan \\ Department of Gender Studies \\ University of Peshawar
}

\begin{abstract}
It is human nature that we tend to stereotype certain individuals and groups based on their ethnicity, race, religion, and even looks, among other attributes. That is the case with Pakhtuns as well. Non-Pakhtuns, within and outside Pakistan, do not have a very positive notion about them; more so about their treatment of women. In this paper, I demonstrate that there is no doubt that the Pakhtuns are restricted, in some cases, by their cultural boundaries but then everyone, irrespective of their ethnic, racial, and/or religious backgrounds have their limitations. In order to prove my stance I have first of all interviewed some native Pashto speakers to get a general understanding about and usage of Pashto tappa and contemporary poetry composed by women. Using Althusser's framework of ideology and Ideological State Apparatus, as the theoretical foundation, I argue that Pakhtun women are culturally interpellated but they have their own ways of practicing their agency. These women may not be able to totally challenge structural and cultural norms but they definitely know how to use their quotidian agency. Finally, I conclude that agency should not be understood in the narrow sense; it can have different meanings for different people in different contexts.
\end{abstract}

Key words: Pakhtun women, Pashto Tappa, Ideology, Interpellation, Agency.

\section{تلخيص}

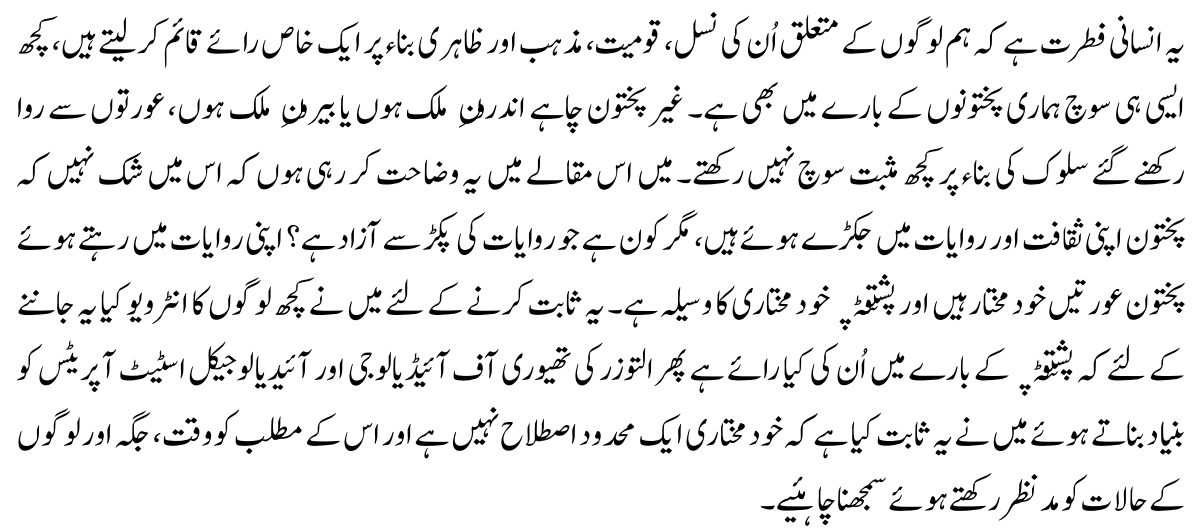

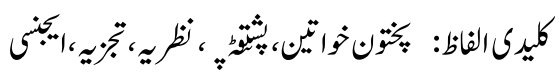




\section{Introduction}

"Seeing is believing" is a rather clichéd English phrase; nonetheless this phrase carries weight. Perhaps, it holds true for the Pakhtuns as well. Before 9/11 and more so after the tragedy Pakhtuns have been stereotyped even more. As elsewhere I have stated, "A common notion among many Pakistanis even today is that the Pakhtuns/Pashtuns or Pathans ${ }^{1}$ are woodcutters, children-abductors, and violators of women rights; in short they are barbarians of a stone-age, living in some remote and rugged lands! The West ${ }^{2}$ erroneously perceives Pakhtun men as Talibans and the women as the burqa-clad (veiled), both of whom epitomize religious and cultural radicalism. In other words, Pakhtuns are regarded as a gender biased, gender segregated (spatially and emotionally), and a patriarchally structured people (Khan, A., 2012a; and Khan, A. 2012b). However, to judge someone or something it is better to get to know them, even slightly.

In this paper, I demonstrate that there is no doubt that the Pakhtuns are restricted, in some cases, by their cultural boundaries but then everyone, irrespective of their ethnic, racial, and/or religious backgrounds have their limitations. By using Althusser's framework of ideology and ideological state apparatus I argue that Pakhtun women are culturally interpellated but they have their own ways of practicing their agency. These women may not be able to totally challenge structural and cultural norms but they definitely know how to use their quotidian agency. In order to explicate my stance I use Pashto folk, especially the genre of tappa and some contemporary poetry, composed by women, as examples. Finally, I conclude that agency should not be understood in the narrow sense; it can have different meanings for different people in different contexts.

\section{Literature Review: Establishing the Premise, Elaborating the Genre, and Elucidating the Theory}

There is a wide variety of literature in print (Abu-Lughod 1986, 1990, 2008; Briggs 1985; Friedlander 1975; Grierson 1884, 1886; Henry 1975; Jacobson 1975; Karp 1988; Kolenda 1984; Munda 1975; Narayan 1986; Raheja and Gold 1994) that shows how women voice their concerns; comment on the cultural nuances; and hence prove literary expressions as agentive tools for tradition-bound women.

As such, tappa is the most commonly used genre of Pashto folk literature. Pashto folk songs are generally composed in lyrical couplets which are called Landai or more commonly Tappa (plural: Tappay). Mohmand (2010, n.p.) explains that Pashto folk songs are couplets of a unique cadence, authored mostly by females addressing their lovers. Their authorship has remained anonymous for all these centuries. Tappay have been sung over hill and vale and before the practice of printing tappay were learned by heart and passed down by the word of mouth. According to Mohmand (2010, n.p.) every 
verse ends with a (stretched) "aa" sound as a mark of exclamation. Each verse is composed of twenty two syllables. The first line with nine syllables is shorter than the following line with thirteen syllables. The shortfall is made up for during singing with expressions of love and pathos differing from area to area. The themes vary from love to social problems, nationalism, patriotism, and even anathema and sarcasm.

According to Shah (2011, n.p.) some tappay begin with a fond opening phrase of " $y a$ qurban!" (Oh, dear one!), meaning respect to the listener. Tappay are sung with loud melodious voice and could be accompanied by mangay, tabla, baja, and sitar. ${ }^{3} \mathrm{He}$ elaborates that tappay are generally sung at weddings, other celebrations and at times without any celebratory occasion. A tappa can be about human emotions, achievements, heroes, villains, and the environment.

Enevoldsen (2004) states that most of the tappay currently used are made by women. Romantic in nature most tappay deal with the lover and the beloved. A related theme is that of separation, "not only of the lover from the beloved, but of friends and of a man from his country and his family" (p. xiii).

Khan, Q. (2008) also affirms that tappa is "essentially a feminine form, mostly composed and sung by women. It is also essentially an anonymous form, usually extempore and unwritten" (p. 10). He also adds that the older people usually use tappay related to religion and morality. Whereas, the younger lot quote romantic, nationalistic, and idealistic tappay (p.12)

As explicated above and later expressed by my respondents tappay tend to express everyday issues, emotions, and happenings in the life of a person in a simple and yet powerful manner. Besides, as I read and was told that most of the Pashto tappay were composed by women though they come down to generations anonymously. Therefore, I use tappa as an example to explicate my stance because it is widely used by native Pashto speakers.

I argue that tappa is one of the many ways through which Pakhtun women practice their quotidian or everyday agency. In order to validate my argument I use Althusser's (1971) theoretical framework of ideology and ideological interpellation. According to Althusser (2005) ideology is a system of representations, having nothing to do with consciousness and influencing men and women through structures unawares (p. 233). As such, Ideology is an unconscious process which acts through structures and is a process that escapes men and women. Althusser (1971) calls these structures Ideological State Apparatuses (ISAs) which include family, educational, religious, and legal institutions, media, and culture among others. Along with ISAs, Althusser (1971) states, that there are the Repressive State Apparatuses (RSAs) as well. These include the government, the administration, the army, the police, the courts, the prisons, etc. (p.145). However, the difference between 
these two types of state apparatuses is that ISAs function through consent, whereas RSAs function through violence and coercion. As such, ISAs influence individuals unaware and are always at work without the conscious knowledge of the individuals.

According to Althusser (1971) ISAs interpellate or hail social individuals and when these social individuals respond to the interpellation they become social subjects. As a result of interpellation, the "process of recognition" begins and the individual can either accept or reject a subject-position or else he or she can agree to disidentification. According to Pêcheux (1982, pp. 156-159), the individual who responds to and accepts the interpellation or the hailed position is called a universal subject and the one who refuses to comply is the subject of enunciation. The universal subject or the "good subject" is the one who abides by the expected social and cultural norms whereas the subject of enunciation or the "bad subject" does not. Besides, accepting or rejecting a social subjectposition, a social subject can adopt disidentification which constitutes "working of the subject-form and not just its abolition" (Pêcheux 1982, p. 159). As such, in this paper I demonstrate that Pakhtun women respond to the cultural interpellation and respond as the disidentifying subjects by using tappa as means of their quotidian agency.

In anthropological and sociological literature agency has multi-tiered meaning(s) and the notion can be expressed and practiced in various ways in different cultures, structures, and circumstances. Ahearn (2001) defines agency as, "the socioculturally mediated capacity to act" (p. 112). And Mahmood (2001) believes that "[the] ability to understand and interrogate the lives of women whose desire, affect, and will have been shaped by nonliberal traditions... think of agency not as a synonym for resistance to relations of domination, but as a capacity for action that historically specific relations of subordination enable and create" (p. 203). And Hilsdon (2007) believes that agency is something that arises from within the discursive discourses (p. 127). Therefore, Raval (2009) believes that women who grow in different cultures are bound to internalize desires according to their respective situations (p. 492). Correspondingly, Heron (2008) states, "When it comes to human agency, people make choices, motivate and regulate their behaviour on the basis of belief systems and cultural backgrounds" (p. 87). Keeping in view the opinions of these scholars agency is a temporally, culturally, and socially contextualized phenomenon.

As such, literary expressions, whether in the form of folk songs or published poems, should be understood and accepted as agentive tools used by women in the Pakhtun culture that may not change the cultural power dynamics but they definitely create some awareness among both men and women and to an extent challenge the cultural taken-forgranted perceptions. Finnegan (1991) explains that in order for a folk tradition continue it has to be used by its people; whether its followers exploit, change or follow it blindly (p. 112). And Geertz (2003, p. 36) believes, "But that is what listening to the voices of our own literary tradition...brings on as well: the sense that there is more to things than first 
appears and that our reactions are where we start, not where we end." Abu-Lughod (2008) also categorically discusses the importance of songs and stories as a medium of expression in traditionally gendered societies.

\section{Methodology: Method, Field Site, and Respondents}

For this paper, apart from using and analyzing Pashto tappay, I have included few lines from some contemporary Pashto poetry by women as well. Besides, I have also interviewed three respondents, two men and a woman. I purposively selected Pakhtuns research respondents residing in Peshawar. These respondents belong to different parts of Khyber Pakhtunkhwa (KP) and are native speakers of Pashto; Pashto being their mother tongue. The respondents are between 30-50 years old. And I intentionally interviewed respondents who were educated and by educated I mean that these respondents have a masters, M. Phil, or PhD degree. The reason I interviewed educated people was that I wanted to know how far, if at all, the educated, comparatively exposed, and what we call "modern" Pakhtuns use the traditional and colloquial language. Since my research is ethnographic in nature I include some verbatim responses of the research participants.

\section{Tappa: The Gendered Voice}

During my discussions with my respondents it was apparent that like any culture even among Pakhtuns poetry is a dominant form of literary expression. However, I was told that folk literature and especially tappa, as a form of literary genre, was more popular among the masses than any other literary genre.

Nadia, a young academic whose research focuses on Pakhtun culture began by reiterating the fact that tappa is the most common form of expression. She explained, It maybe because its wording and composition is very comprehensive; and one tappa can convey many things at a time. Secondly, it is popular because most of the Pakhtuns are familiar with its content. There are multiple themes in tappa, for example, bravery, nung (respect), ghairat (honor), peghore (taunt); everything that is there in the Pakhtun culture. Tappa is also a struggle to maintain the Pakhtun cultural norms, for example, the ideals of masculinity and femininity.

Another respondent, Daud, was of the opinion that tappa is the most popular genre in Pashto literature. It is very popular in the rural areas. The illiterate or the not trained in modern education use tappa a lot, "you will see them working in the field and singing tappay." He also explained that Pashtun women know a lot of tappay and they use them on different occasions according to the context. However, Daud also said, "Our educated 
lot do not know much about tappa because I think they are more attracted towards the modern media, Hollywood, and Bollywood music."

Accordingly, the usual themes of tappa are about life: anything that is related to life. It is the most popular form because its composition is simple. As Daud pointed out, "It is folk poetry therefore it is pretty much close to the aspirations, the worries, the life of common man and woman. It speaks of the common person's life. It is short; so you can remember it very easily. It is precise and comprehensive."

In the following section I quote some tappay, their translation and explanation to demonstrate their wide thematic range expressing the female voice. For example, Eid is one such festive occasion which culturally sanctions meeting and mixing of relatives and friends. However, there are cultural restrictions that do not allow unrelated men and women to meet and greet. Yet, the beloved passes on a message, usually sung, that:

Janana rasha ka me gore

Pa sro jamo ke laka gul walara yama (Mohmand, 2010, p. 3)

(Darling come if you want to see me

In a red dress I stand like a rose (translation by author)

Te da akhtar pa sahar rasha

Za ba dar-oozam thore starge sra laasoona (Mohmand, 2010, p. 28)

(Come over on Eid morning

I'll come out, kohl eyed and henna-stained hands) (translation by author)

Both these tappay are in the female voice because firstly the gendered verb endings (as in Udru) are female. Secondly, the dress code and the make-up (red dress like a rose; kohl eyed and henna stained hands), respectively, show that it is a woman who is suggesting to her lover to meet her on Eid. Besides, the persona is dressed up for this meeting; she will not meet her lover shabbily dressed. Amongst the cultural restraints this is how she practices her quotidian agency.

Furthermore, it is interesting to see Pakhtun women, particularly in the rural areas, are so explicit in voicing their concerns about their sexual and personal desires. Whether these emotions are sung in public domains, as in all-female gatherings, or expressed privately among female relatives and/or friends, I think it bears to the fact that these women have the space and the agency to express their emotions unlike many others.

\section{Zama janam nadaan halak de}

Che khulgai warkrham beya dae waee haloona (Mohmand, 2010, p. 36)

(My lover is a naïveté

When I kiss him he tells our secret to all) (translation by author) 


\author{
Zama chargul ke sa guna wa \\ Ta ba da sro anango na akhistal khwandoona (Mohmand, 2010, p. 37) \\ (Don't blame my jewellery \\ You could have still relished on my cheeks) (translation by author) \\ Seena palang leche balakhth de \\ Zama napoya yar pe sar na lagaweena (Mohmand, 2010, p. 40) \\ (My bosom the bed, my wrists the pillow \\ My naïve lover doesn't recline) (translation by author) \\ Da beganae ajaba shpa va \\ Da che da yar pa gheg ke laka panrha rapedama (Mohmand, 2010, p.14) \\ (It was, indeed, the night of all nights, last night \\ When I quivered as a leaf pressed to his bosom tight)
}

The above tappay, that is, in Pashto, through their linguistic markers suggest the female voice. The persona talks about janan halak (lover-boy); zama chargul (my jewelry); seena palang (bosom - the bed); rapedama (shivering and the verb has a feminine ending).

Besides, the women practicing quotidian agency by singing tappay themselves, there are other tappay where the female concern about (dis)honor, (dis)respect, (in)equality, etc. are voiced in a perhaps masculine or apparently gender-neutral voice. Nonetheless, the aim is the wellbeing of the women which eventually lets them not only become aware of their traditional limitations but is in fact a way of consciousness raising of the Pakhtun men as well. As such, indirectly, such tappay advance the cause of Pakhtun women's quotidian agency. For instance, the following tappay underscore this claim:

De Pakhtun dae Pukhto taa gora

Che loor ao khor laka sarwee baya kawee na

(Imagine the Pakhtun's sense of honor

He sells his sister and daughter like cattle) (translation, Khan, Q., 2008, p. 23)

De khazay marg ta haajat neeshta

Bala pe okra da ae marg dae; mra ba sheena

(There is no need to kill your wife

Just marry another one, she will die herself) (translation, Khan, Q., 2008, p. 24)

Da ser ao maal khatra pakay wee

Cha che dwa banay pa yao kor saa talay wee na

(It is dangerous for both your health and wealth,

To keep two wives at the same time) (translation, Khan, Q., 2008, p. 24) 
Similarly a verse of a song, in a male voice, shows the cultural limitation of a man who wants to greet his beloved but is conscious of the societal stigma that may be attached to a single woman meeting and greeting a single, unrelated (or even related) man:

Zra raa ta waiyae che wersha tae pukhtana oka

Galay che paata shawuma da mae sta haya ta katal

(My heart bids me to inquire about you

Keeping your honor in mind, I kept quiet) (Translation by author)

One of my respondents, Yasir, a man in his early 50s gave a plausible explanation of how Pakhtun women practice agency. He believed that the relationship a woman is in determines her level of agency. He was of the opinion that perhaps a woman of herself and in-herself does not have much agency because Pakhtun society respects relations. $\mathrm{He}$ explained that literature has played a role in giving some agency to women. He thought folk literature gives more agency to women since it comes first in oral form then the written form. There are certain forms which are specifically the domain of women. The voice is that of woman; the composition comes from a woman; the participation, and the performance of emotions is mostly that of a woman; like for example the tappa is perhaps the sole form which is specifically a form in which women specialize in. They compose these during celebratory activities and during mournful activities. And during activities that perhaps shows reflection of a woman on the political, economic, and social, issues she finds around herself. In addition to these collective spheres tappa is also used for the individual sphere where woman expresses her emotions as an individual. Most of the folk stories like "Adam Khan- Durkhanay", "Yousuf Khan-Sher Bano", or any other for that matter, the role assigned to woman seems to be more powerful than the one assigned to the man. Why? Because it is actually the woman who works a pivot or what John Donne calls the stationery leg of the compass and the man revolves around that leg. Or for man, woman is the emotional hub; the emotional nucleus. For example, Yasir quoted a tappa from the folktale of "Sher Alam Khan-Maimoonai", and explained that in this tappa the voice is that of a woman, "my requests bought you from the other end of the world/but how do I bring you back from the world of the dead?" The background being that in "Sher Alam Khan-Maimoonai", Sher Alam came back from India for her but then his paternal cousins murdered him. Yasir emphatically stated, "Imagine the power she has; imagine the agency. I would say that mother, daughter or sister would not exercise that power over man. But then that agency is available to a woman if she is in a social, legal or at times even in a biological relationship."

Yasir was also of the opinion that tappa is the most popular genre of folk literature because it is public property; perhaps no researcher actually knows when it actually started. He thought it started with the heart beat - whenever the Pakhtun heart beat the first time at that time the tappa was born. Furthermore, the language in it is really very simple. It uses very colloquial expressions; it does not depend upon the beauty of the language; it does not 
depend upon the conventional figures of speech; the main focus is on the idea. The main focus is on the body; it is not the cosmetics. Yasir reiterated the fact that some tappay are really very simple but if one looks at the thought process and the strings attached to the thought process some of them are really very loaded for example:

Che maazigar tanoor ta kae numa

Loogay bana kum jera taa pasay koama

(In the evening when I bake bread

I cry and tell people the smoke brings tears to my eyes) (translation by respondent)

This is indeed a loaded tappa. It is a comment on how woman is repressed because she cannot even openly perform her emotions of missing her love. Perhaps, because showing a sign of weakness will make her less of a woman. Or perhaps, one is not supposed to publically show one's emotions. Or perhaps, there are other problems which are more pressing than missing one's love. For example, most Pakhtuns work abroad on minimum wage and how they and their families or loved ones do not want to stay away from each other. But then there is a bigger need; the physical need is perhaps prior to the emotional need. The voice is in this tappa wants to admit that she has this emotional need too. But she would not want to come across as a weakling. She would not want to come across as somebody missing her love because in the absence of her husband or father she may be the head of the family and she does not want her family members to see her as a weak person. Because given the environment that the Pakhtuns have seen and continue to see even today if the male family member is not there the rest of the family members will look up to the elder woman and one would assume that if she is baking bread at the tanoor or clay oven it is not only literal or physical but also metaphoric; she is providing bread for the family members. And if the elder of the family shows weakness she will not be in a position to explain to the rest of the family members why the man in their life is not there or how she is capable of fulfilling his duties.

However, another way to look at this tappa would be that how oppressive the society is which does not perhaps allow woman to publically display her emotions about how she is missing her love, or her fiancé, or her husband. And by not publically displaying her emotions she is singing it! This woman is so mindful of the physical limitations but at the same time is also admitting that she has her emotional needs too. So she would rather blame the smoke from the tanoor or clay oven to be responsible for the tears that she is shedding than to admit that she is missing someone. But it is noteworthy to see how she is performing her emotions of missing him and yet not publically admitting it. No doubt, it is a very bleak comment; a cutting comment on Pakhtun society in not giving woman that liberty, that agency where she can express her emotions. And that agency is provided by tappa which is why perhaps it is very popular. And it is equally popular among men and women. 
Almost all tappay, with a few exceptions here and there, are sung by men. Perhaps it is an attempt to compensate for what Pakhtun men deny women in real life. So they sing women's songs. And the voice men do not allow her they sing those songs to accompaniment of music and to the traditional gathering of men. And in a way language and tappa gives woman that power which she cannot have in her personal sphere; it is a voice that she acquires, though a little twisted too, and sings it to everyone. So it seems as if the physical voice is what is denied to woman but the voice or the person who speaks to us in the tappa is actually celebrated. Pakhtun man in a very compensatory manner acknowledges this power.

With regard to Pashto folk songs Salma Shaheen, a Pashto scholar and poet, says, We have $85 \%$ folklore that is created by women. Why they created it is because they are the marginalized class. These Pakhtuns have a strange psyche... where [romantic] interest is generated or developed, there has to be a separation. You cannot meet anyone [you like]. When you cannot meet anyone, you are unhappy and when you are unhappy art is created... for creativity separation is necessary.

Apart from folksongs and literature there are Pakhtun women who are housewives, working women, or both and at the same time are poets as well. Besides, personal issues these women raised environmental and social questions. One of them said,

The fresh blowing breeze of the city

Now whimpers through the skyscrapers

The jasmine and roses

Now await their gardener

The night-glory in my courtyard

Now yearns for a drop of water.

The second poet said,

I will only come when

The sky turns azure

The flower beds turn red

The mustard flowers bloom yellow.

What is the ratio of hatred

In the village-winds now?

I will only come when

The hearts are cleansed.

Come my dear!

I will take thee to my village

It has been a while in foreign lands

That I have been venting my emotions. 
These poems and the tappay illustrate that Pakhtun women, depending on their level of education, social status, and access to opportunities have various ways of practicing their agency, either quotidian or restricted.

\section{Conclusions}

Althusser (1971) believes that all social individuals become social subjects when they respond to an ideological interpellation. However, their subject position is determined by the way they react to the interpellation, that is, as a good, bad, or a disidentifying subject (Pêcheux, 1982). Besides, ideology always needs a conduit, which Althusser calls the Ideological State Apparatuses (ISAs), to interpellate an individual. Among others, culture is a strong ISA which interpellates both men and women. But Pakhtun men and women respond differently to the cultural ideological interpellation. Most Pakhtun men respond as the good or disidentfying subjects; yet some also afford to be the bad subjects. However, most Pakhtun women only respond as good subjects by abiding by the gendered cultural norms and expectations. As most Pakhtun women cannot respond as bad subjects due to cultural censures therefore they resort to a disidentifying subjectpositions and use tappa, the most popular and accepted genre of folk literature, to voice their concerns and emotions. Since the disidentifying subject adopts a middle path as the not-so-good and the not-so-bad subject, therefore by using tappa as a form of expression, these women are not considered cultural rebels. Therefore, composing and singing or even prosaically uttering tappay give Pakhtun women quotidian agency of sorts.

In this paper, I wanted to demonstrate that according to the non-Pakhtun standards Pakhtun women may have restricted agency or perhaps no agency. However, one of the ways to practice that agency within restricted cultural structures is through the use of folk and contemporary literary genres.

Alcoff (1988) believes, the position of women can actually become the location of constructing meaning rather than the place where meaning can be discovered (p. 434). In addition, Raheja and Gold (1994, p.123) aptly justify women's folk songs by stating that in many cultures women's relationships are not given primary importance so these women use these folk songs as a way to challenge some tenets of the cultural discourse . As such, Pashto poems and folksongs prove to be the medium that strategically voice and advocate social, cultural, and gender issues. Hence proving that that agency should not be understood in the narrow sense; it can have different meanings for different people in different locales; at different times, and in different contexts.

\section{End Notes}

1. Pakhtuns/Pukhtuns/Pukhtoons and Pashtuns are orthographic and linguistic variants used for the same ethnicity. The difference in pronunciation of the "kh" and "sh" sound is due to the two different dialects spoken in the northern and southern districts, respectively, in Khyber Pakhtunkhwa, Pakistan . The British, following the Indians, used the word Pathan(s) for this ethnic group. 
2. By "West" I primarily mean countries in North America, Europe, and other economically and technologically developed countries that lie to the west of Pakistan.

3. Mangay (or ghara in Urdu) is an earthen pot-bellied pitcher used for producing a hollow sound; tambal is a tambourine-like instrument; baja is the harmonium.

\section{References}

Abu-Lughod, Lila. (2008). Writing Women's Worlds: Bedouin Stories. Berkeley and Los Angeles: University of California Press.

Abu-Lughod, Lila. (1990). The Romance of Resistance: Tracing Transformations of Power through Bedouin Women. American Ethnologist, vol.17:1, pp.41-55.

Abu-Lughod, Lila. (1986). Veiled Sentiments: Honor and Poetry in a Bedouin Society. Berkeley: University of California Press.

Ahearn, Laura M. (2001). Language and Agency. Annual Review of Anthropology, vol.30, pp.109-137.

Alcoff, Linda. (1988). Cultural Feminism versus Post-Structuralism: The Identity Crisis in Feminist Theory. Signs, vol.13:3, pp.405-436.

Althusser, Louis. (2005). For Marx. Ben Brewster, trans. London: Verso.

Althusser, Louis. (1971). Ideology and the Ideological State Apparatuses. Lenin and Philosophy and Other Essays. Ben Brewster, (Trans.). pp.127-186. New York: Monthly Review Press.

Briggs, Charles. (1985). The Pragmatics of Proverb Performance in New Mexican Speech. American Anthropologist, vol.87:4, pp.93-810.

Enevoldsen, Jens. (2004). Spogmai Krang Waha Rakhaeja (Sound the Bells, O Moon, Arise and Shine!): A Collection of Pashto Proverbs and Tappas. Peshawar: InterLit Foundation.

Finnegan, Ruth. (1991).Tradition, but What Tradition and for Whom? Oral Tradition, vol.6:1, pp.104-124.

Friedlander, Eva. (1975). The Mundane and Prosaic in Bengali Folk Songs. Journal of South Asian Literature, vol.11:1-2, pp.131-146. 
Geertz, Clifford. (2003).A Strange Romance: Anthropology and Literature. Professional, vol.1, pp.28-36.

Grierson, G. A. (1886). Some Bhoj'pūrī Folk-Songs. Journal of the Royal Asiatic Society of Great Britain and Ireland, vol.18:2, pp.207-267.

Grierson, G. A. (1884). Some Bihārī Folk-Songs. Journal of the Royal Asiatic Society of Great Britain and Ireland, vol.16:2, pp.196-246.

Hennessy, Rosemary. (1993). Women's Lives/Feminist Knowledge: Feminist Standpoint as Ideology Critique. Hypatia, vol.8:1, pp.14-34.

Henry, Edward O. (1975). North Indian Wedding Songs. Journal of South Asian Literature, vol.11:1-2, pp.61-93.

Heron, Taitu. (2008). Globalization, Neoliberalism and the Exercise of Human Agency. Theme Issue, "The New Sociological Imagination III," International Journal of Politics, Culture, and Society, vol.20:1/4, pp.85-101.

Hilsdon, Anne-Marie. (2007). Introduction. Reconsidering Agency-Feminist Anthropologies in Asia. The Australian Journal of Anthropology, vol.18:2, pp.127-137.

Jacobson, Doranne. (1975). Songs of Social Distance. Journal of South Asian Literature, vol.11:1-2, pp.45-59.

Karp, Ivan. (1988). Laughter at Marriage: Subversion in Performance. Journal of Folklore Research, vol.25:1-2, pp.35-52.

Khan, Anoosh. (2012a). Contesting Subjectivities, Negotiating Agency, and Re-defining Boundaries: The Ideological Identity Formation and Positioning of Pakhtun Women. Ph.D Dissertation. The American University, Washington D.C., USA.

Khan, Anoosh. (2012b). Anthropology, Feminism, and Literature: Blurring Boundaries. The Journal of Humanities and Social Sciences, University of Peshawar, vol.20:2, pp.37-56.

Khan, Qabil. (2008). The Tappah: Reflection of Pakhtoon Culture in Pashto Folklore. Peshawar \& Islamabad: Pashto Academy \& Lok Virsa. 
Kolenda, Pauline. (1984). Woman as Tribute, Woman as Flower: Images of "Woman" in Weddings in North and South India. American Ethnologist, vol.11:1, pp.98-117.

Mahmood, Saba. (2001). Feminist Theory, Embodiment, and the Docile Agent: Some Reflections on the Egyptian Islamic Revival. Cultural Anthropology, vol.16:2, pp.202-236.

Mohmand, Arbab Hidayatullah. (2010). Solitaires: Tappé: Songs Forever. Peshawar: Spinzer Printers.

Munda, Ram Dayal. (1975). A Few Bengali Vaisnava Folk Songs. Journal of South Asian Literature, vol.11:1-2, pp.117-129.

Narayan, Kirin. (1986). Birds on a Branch: Girlfriends and Wedding Songs in Kangra. Ethos, vol.14:1, pp.47-75.

Pêcheux, Michel. (1982). The Subject-Form of Discourse in the Subjective Appropriation of Scientific Knowledges and Political Practice. In Language, Semantics, and Ideology. Harbans Nagpal, (Trans.). pp. 155-170. New York: St. Martin's Press.

Raheja, Gloria Goodwin and Ann Grodzins Gold. (1994). Listen to the Heron's Words: Reimagining Gender and Kinship in North India. Berkeley: University of California Press.

Raval, Vaishali V. (2009). Negotiating Conflict between Personal Desires and Others' Expectations in Lives of Gujarati Women. Ethos, vol.37:4, pp.489-511.

Shah, Rahmat. (N.d.). Tappa. Accessed November 28, 2011. http://www.khyber.org/ culture/music/tappa.shtml.

Prof. Dr. Anoosh W. Khan is Chairperson in the Dept of Gender Studies, University of Peshawar. 